\title{
Sagacity about SARS among University Students
}

\author{
Tayyaba saher* and Muhammad Imran Qadir \\ Bahauddin Zakariya university Multan, Pakistan \\ *Corresponding author: Tayyaba saher, Bahauddin Zakariya university Multan, Pakistan
}

\begin{abstract}
The present study was objected to check the awareness about SARS among scholars of university. The pupil of Bahauddin Zakariya university Multan acted as the subjects for this research. Total of 109 subjects showed consent to be the part of this study. Severe acute respiratory syndrome (SARS) is considered a deadly animal virus which, perhaps originated from bats and then it was spread to other animals. According to a report, the humans were affected by SARS very firstly in 2002 in Guangdong, china. a report by World health organization states that 8098 people were affected by SARS in an outbreak during 2003, out of which 774 died. It was first observed as an influenza like disease with headache, fever leading to failure of respiratory system and sometimes death of the patient. The early symptoms of SARS are headache, body ache, high fever, coughing and sneezing, feeling difficulty in breathing leading to asthma sometimes. Treatment of SARS includes taking antibiotics (to prevent pneumonia) and some antiviral medicines. Present research helped in knowing about the knowledge of SARS in university students. This study helped in estimating that $84.40 \%$ pupil consider SARS as a viral disease, $12.84 \%$ students think it's a genetic problem while $9.17 \%$ suppose it's a metabolic error.
\end{abstract}

Keywords: SARS (severe acute respiratory syndrome); Pupil; Ailment; Viral; Metabolic; Pandemics; Steroids

\section{Introduction}

Severe acute respiratory syndrome (SARS) is considered a deadly animal virus which, perhaps originated from bats and then it was spread to other animals. Viruses have the highest mutation rate among all living organisms. Many lethal infectious pandemics are considered to have been evolved from animals which then mutated and transmitted to humans. HIV, avian flu, SARS and swine flow are examples of such viruses. According to a report, the humans were affected by SARS very firstly in 2002 in Guangdong, china. a report by World health organization states that 8098 people were affected by SARS in an outbreak during 2003, out of which 774 died. It spread in other parts of the world by people who travelled or visited the vulnerable places. coronavirus family, which mostly attacks the respiratory tract and gut of mammals and cause some well-known viral diseases like common cold. Almost $15-30 \%$ of common colds are caused by these viruses. A member of this family of viruses is responsible for SARS which is a serious form of pneumonia. It was first observed as an influenza like disease with headache, fever leading to failure of respiratory system and sometimes death of the patient. On 12 April 2003, the gene sequence of corona virus was completely mapped by Michal smith genome sciences center, it was considered to be linked with SARS. It is a single stranded and enveloped RNA corona virus having genome of $29.7 \mathrm{~kb}$ (kilobases), which is considered the largest genome among viruses. SARS virus contains 13 identified genes and 14 identified proteins. Big pleomorphic spherical particles are possessed by these viruses with some large bulb like projections appearing on the surface which gather to form corona around the particles. Lipids mostly form the envelope of these viruses. The early symptoms of SARS are headache, body ache, high fever, coughing and sneezing, feeling difficulty in breathing leading to asthma sometimes. Some of the Less common symptoms are dizziness, diarrhea, nausea and vomiting, runny nose and sore throat. It is spread mostly by the respiratory secretions, like droplets, of the patient. sometimes also transmitted by feces or air but these are not the major route of viral transmission. People who have a close contact with the victims of this disease, like family members or healthcare workers or other patients residing at the same place, are at a high risk of getting the virus from the patient. While examining the person with symptoms of SARS, healthcare worker may hear abnormal lung and chest sound with a stethoscope, pneumonia is usually shown after chest x-ray which comes mostly with SARS. Common tests used to diagnose SARS are arterial blood test, blood clotting test, complete blood count (CBC) and some antibody tests but these tests usually cannot 
identify SARS especially at early stage of infections because of their limitations. Complications during the treatment may include liver and heart failure with disturbance in respiratory tract. Treatment of SARS includes taking antibiotics (to prevent pneumonia) and some antiviral medicines. To minimize the swelling of lungs, some steroids are suggested along with the chest therapy. Liquid blood part(plasma) is taken from the survivors of SARS and injected to the patients in serious condition. The present study was objected to check the awareness about SARS in scholars of university.

\section{Material and Methods}

(Figure 1)

\begin{tabular}{l|l|l|l|}
\hline \multicolumn{1}{|c|}{ A } & \multicolumn{1}{|c|}{ Column2 } & Column \\
\hline Column1 & yes & no \\
\hline is SARS a viral ailment? & & \\
\hline is SARS a bacterial ailment? & \\
\hline is SARS a fungal ailment? & \\
\hline is SARS a genetic ailment? & \\
\hline is SARS a metabolic ailment? & \\
\hline have you ever suffered from SARS disease? & \\
\hline any of your family members have ever suffered from SARS disease? & \\
\hline any neighbour of yours ever met with this disease? & \\
\hline any related person to you have ever experienced this disease? & \\
\hline does any friend of yours ever suffered from SARS? & \\
\hline can SARS be transmitted by blood transfusion or contact to other persons? & \\
\hline can SARS be transmitted from parents to their children? & \\
\hline can SARS be treated by medicine? & \\
\hline any surgery is needed to cure SARS? & \\
\hline any treatment is needed to heal SARS or not? & \\
\hline
\end{tabular}

Figure 1

\section{Project Designing}

The table given in materials and methods is a questionnaire. The pupil of Bahauddin Zakariya university Multan acted as the subjects for this research. Total of 109 subjects showed consent to be the part of this study. The subjects were asked the questions given in the table. Their answers were recorded, and data was collected and compiled.

\section{Statistical Analysis}

The software used to analyze the data obtained was MS Excel.

\section{Results and Discussion}

(Table 1)

Table 1: SARS sagacity in university pupil is shown in above table.

\begin{tabular}{|c|c|c|c|c|c|c|}
\hline \multirow[t]{2}{*}{ S.no. } & \multirow[t]{2}{*}{ Question } & \multicolumn{2}{|c|}{ Male } & \multicolumn{2}{|c|}{ Female } & \multirow{2}{*}{$\begin{array}{c}\text { Total } \\
\text { Yes } \\
\end{array}$} \\
\hline & & Yes & No & Yes & No & \\
\hline 1 & Is SARS a viral disease? & 0.7916 & 0.2083 & 0.94 & 0.06 & 0.844 \\
\hline 2 & Is SARS a bacterial illness? & 0 & 1 & 0 & 1 & 0 \\
\hline 3 & Is SARS a fungal disease? & 0 & 1 & 0 & 1 & 0 \\
\hline 4 & Is SARS a genetic problem? & 0.1041 & 0.8958 & 0.0769 & 0.923 & 0.1284 \\
\hline 5 & Is SARS a metabolic error? & 0.0416 & 0.9583 & 0.0576 & 0.9423 & 0.0917 \\
\hline 6 & Have you ever suffered from SARS? & 0 & 1 & 0 & 1 & 0 \\
\hline 7 & Any of your family member ever suffered from SARS? & 0 & 1 & 0 & 1 & 0 \\
\hline 8 & Any relative met with SARS earlier? & 0 & 1 & 0.0576 & 0.9423 & 0.0733 \\
\hline 9 & Any neighbor of yours ever suffered from SARS? & 0.1875 & 0.8125 & 0.0769 & 0.923 & 0.1758 \\
\hline 10 & Any friend of yours ever undergone SARS? & 0.0625 & 0.9375 & 0 & 1 & 0.0733 \\
\hline 11 & Can SARS be transmitted by blood transfusion and contact? & 0.25 & 0.75 & 0.5961 & 0.4038 & 0.4758 \\
\hline 12 & Can SARS be transmitted from parents to younglings? & 0.2708 & 0.7291 & 0.25 & 0.75 & 0.3058 \\
\hline 13 & Can SARS be treated by medicine? & 0.6666 & 0.3333 & 0.9807 & 0.0192 & 0.8758 \\
\hline 14 & Any surgery can cure SARS? & 0.2083 & 0.7916 & 0.0384 & 0.9616 & 0.1559 \\
\hline 15 & No treatment is needed for SARS? & 0.1666 & 0.8333 & 0 & 1 & 0.1192 \\
\hline
\end{tabular}


A meaningful advancement in recent researches about SARS has been provided by this questionnaire-based study. SARS has been discussed as an important issue worldwide by scientists. It was examined that bat SARS-cov strains were magnificently similar to human SARS r-cov in ORF3b and ORF8 regions in an article by Ben Hu, Lei-Ping Zeng, Xing-Lou Yang, Xing-Yi Ge, Wei Zhang, Bei Li, Jia Zheng Xi, Xu-Rui Shen, Yun-Zhi Zhang, Ning Wang, Dong-Sheng Luo, Xiao Shuang Zheng, Mei-Niang Wang, Peter Daszak, Lin-Fa Wang, Jie CuI, ZhengLi Shi. In a study about knowledge, attitude and awareness towards SARS in Qatar in 2003, it was observed that only $8 \%$ people had accurate knowledge about the signs of this disease and its onset, while $60 \%$ people were afraid to travel for fear of being affected by SARS [1]. In another study about rapid awareness and transmission of SARS in HANOI French hospital Vietnam in 2005, it was concluded that using masks and gowns prevented transmission of SARS in an outbreak. Those doctors and nurses who observed all the rules keenly got better rapidly after the onset of secondary cases. The probability about the extinction of this disease was observed with better improvements in behavior and isolation [2-14].

\section{Conclusion}

Present research helped in knowing about the knowledge of SARS in university students. This study helped in estimating that $84.40 \%$ pupil consider SARS as a viral disease, $12.84 \%$ students think it's a genetic problem while $9.17 \%$ suppose it's a metabolic error. None of the students have ever suffered from this illness nor their family members.47.58\% students think that SARS can be transmitted by blood transfusion or contact from one person to another. $87.58 \%$ students said that they think SARS can be treated by medication. $15.59 \%$ pupil think that surgery can be the cure of
SARS while $11.92 \%$ think that there is no need of treatment for SARS.

\section{References}

1. Bener A, Al Khal A (2004) Knowledge, attitude and practice towards SARS. The journal of the Royal Society for the Promotion of Health 124(4): 167-170.

2. Nishiura H, Kuratsuji T, Quy T, Phi NC, Van Ban V, et al. (2005) Rapid awareness and transmission of severe acute respiratory syndrome in Hanoi French Hospital, Vietnam. The American journal of tropical medicine and hygiene 73(1): 17-25.

3. Qadir MI, Javid A (2018) Awareness about Crohn's Disease in biotechnology students. Glo Adv Res J Med Medical Sci 7(3): 62-64.

4. Qadir MI, Saleem A (2018) Awareness about ischemic heart disease in university biotechnology students. Glo Adv Res J Med Medical Sci 7(3): 59-61.

5. Qadir MI, Ishfaq S (2018) Awareness about hypertension in biology students. Int J Mod Pharma Res 7(2): 8-10.

6. Qadir MI, Mehwish (2018) Awareness about psoriasis disease. Int J Mod Pharma Res 7(2): 17-18.

7. Qadir MI, Shahzad R (2018) Awareness about obesity in postgraduate students of biotechnology. Int J Mod Pharma Res 7(2): 14-16.

8. Qadir MI, Rizvi M (2018) Awareness about thalassemia in post graduate students. MOJ Lymphology \& Phlebology 2(1): 14-16.

9. Qadir MI, Ghalia BA (2018) Awareness survey about colorectal cancer in students of M. Phil Biotechnology at Bahauddin Zakariya University, Multan, Pakistan. Nov Appro in Can Study 1(3): NACS.000514.

10. Qadir MI, Saba G (2018) Awareness about intestinal cancer in university student. Nov Appro in Can Study, 1(3): NACS.000515.2018.

11. www.medlineplus.govt./ency/article007192.html.

12. www.webmd.com.lung/what is SARS.

13. www.cdc.gov/SARS.

14. https.nhs.uk/conditions/SARS.

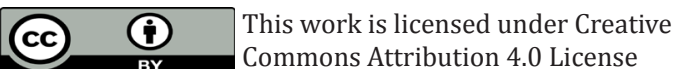

To Submit Your Article Click Here: Submit Article
DOI: 10.32474/OAJOM.2019.02.000145

Citation: Tayyaba S, Muhammad I Q. Sagacity about SARS among University Students. Open Acc J Oncol Med 2(4)- 2019. OAJOM. MS.ID.000145. DOI: 10.32474/OAJOM.2019.02.000145.

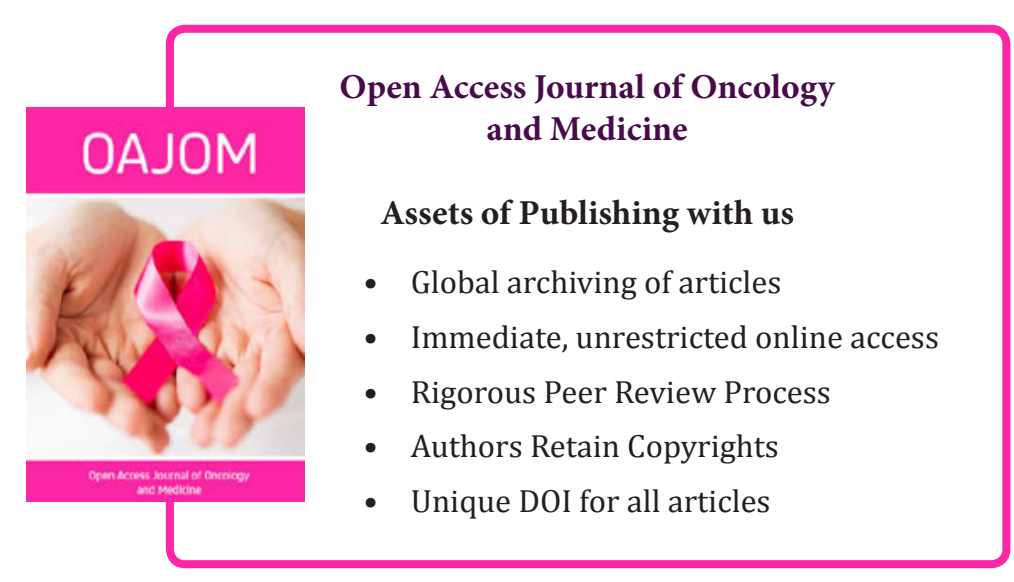

